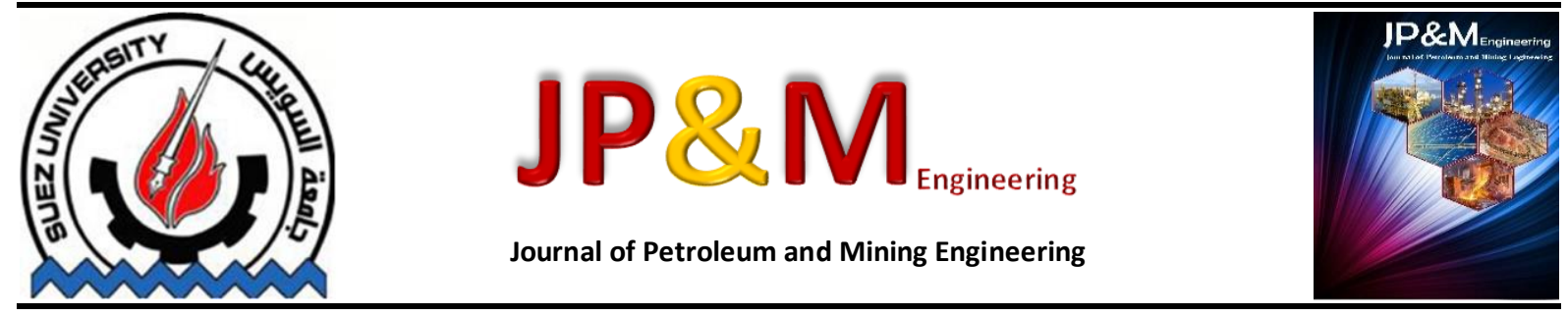

\title{
Safe Storage Design For Naturally Occurring Radioactive Material Waste Using Human Intrusion Scenario
}

\author{
B.S.El-Hussany ${ }^{a}$, F.K.Gad ${ }^{b}$, A.M.Shoaib ${ }^{\text {b* }}$, , A.A.Hamed ${ }^{a}$, N.S.Mohamed ${ }^{a}$, M.M.Abdellatifa \\ ${ }^{a}$ Nuclear and Radiological Regulatory Authority NRRA \\ ${ }^{b}$ Chemical Eng. \& Petroleum Refining Dept. Faculty of Petroleum \& Min eng. Suez University \\ ${ }^{*}$ Corresponding author e-mail: Abeer.shoaib@suezuniv.edu.eg . T: +201004554076
}

\section{Keywords}

NORM management; Radioactive materials safety; waste management

\begin{abstract}
Natural occurring radioactive material (NORM) is a special type of radioactive waste. It is produced from many industries, especially from petroleum and gas industries. Accumulation of NORM in these areas leads to hazard effects on the workers and on the environment. Storage is a necessary step in the management of NORM. Recent years, storage step is extended until the decision of the final destination of this waste. Two design forms are used to store the NORM waste; above-ground storage room, and under-ground bunkers. In the present study, human intrusion scenarios are studied for both storage designs. The results obtained illustrate that the total dose is equal to $4.48 \mathrm{E}-08 \mathrm{~Sv}$ in case of human intrusion above ground storage, and $2.67 \mathrm{E}-03 \mathrm{~Sv}$ in the under-ground bunkers of NORM. The doses calculations show that the storage above-ground is more safe than the storage under-ground bunkers in case of human intrusion scenario.
\end{abstract}

\section{Introduction}

Naturally Occurring Radioactive Materials (NORM) comprises radionuclides associated with the $238 \mathrm{U}$ and 232 Th decay chains as well as 40K. These radionuclides are very long lived and have some progeny that have long lived, such as 226Ra. Radionuclide concentrations are not exceptionally high in common sedimentary materials; however, elevated levels can be found in clay. The radio nuclides tend to exist in equilibrium in rock formation [1-3]. In petroleum industry, NORM is considered waste materials that generated during exploration of petroleum. The concentration of NORM is increased during the different processes. Accumulation of NORM of exploration and production makes a hazard effects on the workers and on the environment. In the absence of final disposal plan, NORM wastes are stored for long-term as interim decision. Above ground storages and /or under-ground bunkers could be used as storage areas.

Scenarios of future human actions have viewed as representations of potential realities based on sets of assumptions. Future human actions can adversely impact radioactive waste systems; these actions must, therefore, be considered in the sitting, the design of waste systems, and in assessments of their safety.

Disruptive human actions can be divided into intentionally disrupted and inadvertently disrupted. Inadvertent actions are defined here as the facility or its barrier system are accidently penetrated or their performance impaired, because the facility location is unknown or its purpose is forgotten by time. Human actions leading to the release of radioactivity and committed intentionally, rather than inadvertently, can be considered the responsibility of the society that takes these actions. Intentional disruptive actions should not be considered in safety assessments. In contrast, actions in which the system is inadvertently disrupted should be considered.

Both disruptive human actions and disruptive natural events can result in the same types of consequences and both are potentially important to safety. Thus, the general quantitative framework developed for safety assessments involving naturally occurring events and processes is also appropriate for the analysis of future human actions. Extensive human judgment is required for the development and modelling of scenarios of both future human actions and natural events and processes [4].

The present work evaluates the safe NORM waste storage design through the scenario of human intrusion. The scenarios are discussed for the long term interim storage for both designs used.

\section{Scenarios Considered}

In the early time of the storage, both storage designs are provided with safe and security measures. However by time, these measures can be failed; 
fences and labels can be deteriorated and /or bunkers places can be disappeared by the action of climatic effects.

\section{Human Intrusion Scenario above the ground:}

It is assumed that a worker (or intruder) exposed suddenly to sandstorm. The intruder took a storage room as a shelter from sandstorm. The storage room has a volume equal $15 \mathrm{~m}^{3}$ and contains barrels and special plastic bags filled with NORM. In the scenario, the intruder is falling on the containers. The likely exposure pathways in this case will be from; 1) inhalation of radon gases spreading in the storage, 2) external exposure from gamma emitters radionuclides and 3 ) ingestion of some soil contain NORM.

\section{Human intrusion scenario in underground bunkers:}

It is assumed that an underground bunker is buried by the consecutive sand storm in the site. After long time, the disposal cover loses its integrity by the effect of time and erosion. Also some of the plastic bags are degraded and the waste with soil is exposed on the surface of the area. Security persons stayed in a room close to the bunker. They spent outdoor during surveillance more than 8 hours per day. They received ingestion, inhalation, and external exposures doses from contaminated soil.

\section{Theoretical model}

\section{Human intrusion scenario for the storage of NORM above the ground}

\section{Exposure dose equations for inhalation}

The decay constant $\lambda$ of the radon is calculated as the following [5]:

$\lambda=\operatorname{Ln}(2) / t_{1 / 2}$

where:

- $\mathrm{t}_{1 / 2}$ is the half-life of radionuclide,

- $\lambda_{2}$ is the decay constant of daughter nuclide.

For ${ }^{222} \mathrm{Rn}$, the release rate of radon from container in air, $\operatorname{Rr}(\mathrm{Bq} / \mathrm{y})$, can be derived using Eq. (2) [6]:

$$
\operatorname{Rr}=\lambda * D_{\text {area }} * A * \rho_{b d} * f
$$

where:

- $\lambda$ is the decay constant of ${ }^{222} \mathrm{Rn}\left(\mathrm{y}^{-1}\right)$

- Darea is the release area permit the release of radon on the containers surface,

- $A$ is the ${ }^{226} \mathrm{Ra}$ concentration in the waste $(\mathrm{Bq} / \mathrm{kg})$.

- $\rho b d$ is the bulk density of the waste in containers $(\mathrm{kg} / \mathrm{m} 3)$

- $f$ is the emanation factor, defined as the fraction of the radon atoms produced which escape from the liquid phase of the waste into the air (in the present case) (dimensionless).

In the present case, it will be replaced by the ratio of ${ }^{238} \mathrm{U}$ activity to the total activity of the wastes.

The associated air concentration of a radionuclide, $\mathrm{C}_{\mathrm{air}, \mathrm{r}}\left(\mathrm{Bq} \cdot \mathrm{m}^{-3}\right.$ ), can be approximated by:

$$
\mathrm{C}_{\text {air }, \mathrm{r}}=\mathrm{R}_{\mathrm{r}} / \mathrm{V}_{\text {air }}
$$

where:

- $\mathrm{Rr}_{r}$ is the release rate of the radon in $\operatorname{air}(\mathrm{Bq} / \mathrm{y})$,

- $V_{\text {air }}$ is the air volume into which the activity released per year is diluted $\left(\mathrm{m}^{3} / \mathrm{y}\right)$

The dose to human due to inhalation of radon gas Doseinh $\left(\mathrm{S}_{\mathrm{v}} / \mathrm{y}\right)$, is given by:

Doseinh $=C_{a i r} * \mathrm{~T} * \mathrm{~b}_{\mathrm{r}} * \mathrm{DF}$ inh

where:

- $\mathrm{C}_{\text {air }}$ is the concentration of the gas in the air $\left(\mathrm{Bq} / \mathrm{m}^{3}\right)$.

- $\mathrm{T}$ is the time spent in the storage area (h),

- $b r$ is the breathing rate of the human $\left(\mathrm{m}^{3} / \mathrm{h}\right)$,

- DFinh is the dose factor for inhalation of radon $(\mathrm{S} / \mathrm{Bq})$

\section{Dose equations for external exposure}

The dose due to external exposure is expressed as:

$\mathrm{D}_{\text {ext }}=\mathrm{A}_{\mathrm{con}} *(24) * \mathrm{DF}_{\mathrm{ext}}$

where:

- Dext is the dose due to external exposure (Sv/y),

- $A_{c o n}$ is the concentration of the radionuclide in the containers in the storage area $(\mathrm{Bq} / \mathrm{L})$.

- (24) is the time considered for the exposure in hours (h),

- DFext is the external exposure dose factor (Sv * $\left.\mathrm{m}^{3} / \mathrm{h} * \mathrm{~Bq}\right)$

Exposure dose equations for ingestion

The dose due to ingestion is expressed as:

$D_{\text {ing }}=Q_{w} * C_{w} * D F_{\text {in }}$

where:

- $\mathrm{Q}_{w}$ is the quantity of liquid waste intake $\left(\mathrm{m}^{3}\right)$. It is assumed equal to $0.0001 \mathrm{~m}^{3}$

- $\mathrm{C}_{\mathrm{w}}$ is the concentration of radionuclides in liquid waste $\left(\mathrm{Bq} / \mathrm{m}^{-3}\right)$

- $D F_{\text {ing }}$ is the dose conversion factor for ingestion (Sv/Bq)

The dose received by an individual in the human intrusion scenario can be expressed as Doset in Sv/Y [7]:

Dose $_{T}=$ Doseinh $_{+}$Dose $_{\text {ext }}+$ Doseing

where:

- Doseinh, Doseext and Doseing are the doses due to the inhalation, external exposure and the ingestion pathways (Sv/y) respectively.

Human intrusion scenario in case of the storage in under-ground bunkers

Assumptions required for the calculation:

- Daily exposure duration is $14.7 \mathrm{~h}$

- Breathing rate $=1.2 \mathrm{~m}^{3} \mathrm{~h}^{-1}$

- Inadvertent consumption of soil rate $=3.4 \mathrm{e}^{-5} \mathrm{~kg}$ $\mathrm{h}^{-1}$

- Dust level $1 \mathrm{mg} \cdot \mathrm{m}^{-3}$ available for inhalation

- Dilution factor resulted from the mixture of soil with waste equal 0.3 [8]. 


\section{Exposure dose equations for inhalation}

The annual individual dose to a human from the inhalation of suspended soil ( $E_{\text {Dust, }}$ in $\mathrm{Sv}^{-1}$ ) is given by:

$E_{\text {Dust }}=\mathrm{C}_{\text {Air }} \mathrm{O}_{\text {Out }} \operatorname{Inh}_{\text {sed }} \mathrm{DC}_{\text {Inh }}$

where:

- $\mathrm{C}_{\text {Air }}$ is the radionuclide concentration in the air above the soil $\left(\mathrm{Bq} \mathrm{m}^{-3}\right)$,

- Oout is the individual occupancy on the contaminated soil $\left(\mathrm{h} \mathrm{y}^{-1}\right)$,

- Inhsed is the breathing rate of human on the contaminated soil $\left(\mathrm{m}^{3} \mathrm{~h}^{-1}\right)$,

- $\mathrm{DC}_{\mathrm{Inh}}$ is the dose coefficient for inhalation(Sv Bq 1)

$C_{\text {Air }}$ given by:

$C_{\text {Air }}=X_{\text {Dry }} C_{\text {Dust }}\left(R_{\text {soil }}-1\right) /$ Rsoil

where:

- $\mathrm{R}$ soil is the retardation coefficient for surface soil compartment (dimensionless),

- CDust is the dust level above the surface soil compartment $\left(\mathrm{kg} \mathrm{m}^{-3}\right)$.

$X_{\text {Dry }}=C_{\text {soil }} /\left(1-V_{\text {soil }}\right) \rho_{\text {soil }}$

where:

- $\mathrm{C}_{\text {soil }}$ is the radionuclide concentration in the soil $\left(\mathrm{Bq} \mathrm{m}^{-3}\right)$,

- $\mathrm{V}_{\text {soil }}$ is the total porosity of the soil (dimensionless)

- and $\rho_{\text {soil }}$ is the grain density of the soil $\left(\mathrm{kg} \mathrm{m}^{-3}\right)$.

$\mathrm{R}=1+\rho(1-\mathrm{v}) \mathrm{kd}_{\mathrm{d}} / \mathrm{vw}_{\mathrm{w}}$

where:

- $\rho$ is the grain density of the medium $\left(\mathrm{kg} \mathrm{m}^{-3}\right)$,

- $\mathrm{v}$ is the total porosity of the medium,

- and $k_{d}$ is the sorption coefficient of the medium $\left(\mathrm{m}^{3} \mathrm{~kg}^{-1}\right)$.

\section{Dose equations for external exposure}

The annual individual dose to a human due to external irradiation from soil ( $E_{\text {Exsoil, }}$ in $\mathrm{Sv}^{-1}$ ) is given by:

$E_{\text {Extsoil }}=C_{\text {soil }}$ Oout $D_{\text {Exts }}$

where

- $\mathrm{Csoil}_{\text {is }}$ is the radionuclide concentration in the soi (Bq $\mathrm{m}^{-3}$ ),

- Oout is the individual occupancy from the contaminated soil $\left(\mathrm{h} \mathrm{y}^{-1}\right)$,

- $D_{\text {Exts }}$ is the dose coefficient for external irradiation (Sv h ${ }^{-1} / \mathrm{Bq} \mathrm{m}^{3}$ ) [9].

\section{Exposure dose equations for ingestion}

Soil can be inadvertently ingested by humans. The annual individual dose to a human from the ingestion of soil ( $E_{\text {sed, }}$ in Svy ${ }^{-1}$ ) is given by:

$\mathrm{E}_{\text {sed }}=\mathrm{X}_{\text {wet }}$ Ing $_{\text {sed }} \mathrm{DC}_{\text {ing }}$

where:

- $X_{w e t}$ is the radionuclide concentration in the soil (Bq kg${ }^{-1}$ wet weight),

- Ing $_{\text {sed }}$ is the inadvertent ingestion rate of soil $(\mathrm{kg}$ wet weight soil $\mathrm{y}^{-1}$ ),
- $\mathrm{DC}_{\text {ing }}$ is the dose coefficient for ingestion (Sv Bq 1),

$\mathrm{X}_{\text {wet }}=\mathrm{C}_{\text {soil }} /\left(1-\mathrm{V}_{\text {soil }}\right) \rho_{\text {soil }}+\mathrm{V}_{\text {wsoil }}$.

where:

- $\mathrm{v}$ is the total porosity $(-)$,

- $\mathrm{V}_{\mathrm{w}}$ is the water filled porosity (-)

- $\rho$ is the density $\left(\mathrm{kg} \mathrm{m}^{-3}\right)$.

$V_{\text {soil }}$ indicates the value for soil, $\rho$ wat indicates the value relates to water.

The total dose from inhalation, external exposure and ingestion is calculated from:

Dose $t=E_{\text {Dust }}+E_{\text {Ext }}+E_{\text {sed }}$

\section{Results}

\section{Sample results}

A sample of contaminated soil was taken from a petroleum company in western desert in Egypt. This sample was analyzed by using Hyper Germanium Detector. Additionally the density of the sample is determined $(1.34 \mathrm{Kg} / \mathrm{m} 3)$. Table 1 , presents the radionuclide detected in the sample with its activity (Uranium, Thorium and Potassium).

Table 1 Results of soil sample analysis

\begin{tabular}{|l|l|}
\hline Nuclide & $\begin{array}{l}\text { Activity } \\
\text { (Bq//kg) }\end{array}$ \\
\hline Total $^{238} \mathrm{U}$ & 814.27 \\
\hline Total $^{232} \mathrm{Th}$ & 508.61 \\
\hline Total $^{40} \mathrm{~K}$ & 234.82 \\
\hline
\end{tabular}

According to the secular equilibrium of Uranium and Thorium decay chains, the activity of different daughter radionuclides calculated by using uranium calculator and is represented in Table 2[10-11]. All radionuclides are in secular equilibrium except ${ }^{218} \mathrm{At}$, ${ }^{234} \mathrm{~Pa}$, ${ }^{212} \mathrm{Po},{ }^{208} \mathrm{Ti}$.

In Table 2, the activities of Uranium, Thorium and Potassium are the source terms of radionuclides involved in the human intrusion scenarios.

Results of human intrusion scenario for the aboveground storage:

The intruder exposed to the radon gas in the storage which is spreading in the whole area. Accordingly he inhaled the radon gas and exposed to an external dose from all radionuclides emitted $\gamma$ rays. The proposal scenario applied in these two types of exposures is continuous for 24 hours. As a reason of unclear vision resulted from the wind storm, he fall on one container. The cover of the container was opened and released the NORM waste on ground. The intruder was assumed to swallow some dust. Consequently, he received an ingestion dose from all radionuclides. The total exposure dose received is calculated in Table 2.

\section{Exposure dose calculations for inhalation}

According to the equation (1), the decay constant of radon is equal $66.57861 \mathrm{y}^{-1}$ where $t_{1 / 2}$ for radon is 3.8 day.

If the storage site contains 75 container/plasticbag that are not totally sealed. Each container is assumed, let a release of radon gas from an opening 
on the cover with area $0.01 \mathrm{~m}^{2}$. The total area permit the release of radon from 75 containers is equal 0.785 $\mathrm{m}^{2}$ (Darea).

From equation ( 2 ), the emanation factor ( $f$ ) is equal 0.071427 , the bulk density $\left(\rho_{b d}\right)$ of the waste is $1.34 \mathrm{Kg} / \mathrm{m}^{3}$ and ${ }^{226} \mathrm{Ra}$ concentration in the waste is $814.7 \mathrm{~Bq} / \mathrm{kg}$; Therefore, the release rate of radon from container and /or plastic bag in air $\left(R_{r}\right)$ is equal $4075.392 \mathrm{~Bq} / \mathrm{y}$.

The yearly rate of air volume is equal to the total volume of storage room $30 \mathrm{~m} 3 / \mathrm{y}$ and consequently from equation (3), Cair is equal $271.6927993 \mathrm{~Bq} / \mathrm{m} 3$.

From equation (4), the time spent in the storage area $\mathrm{T}$ is assumed to be one day ( $24 \mathrm{~h})$. The breathing rate of human is recommended by ICRP (International Commission on Radiological Protection) to be $23 \mathrm{~m}^{3} /$ day. For simplicity, it was assumed in the scenario $1 \mathrm{~m}^{3} / \mathrm{h}$. Consequently, the dose to human due to inhalation of the radon Doseinh is equal 4.29E$8 \mathrm{~Sv}$ according to equation (4).

Table 2 The radionuclide activity calculated from the decay chain of $238 \mathrm{U}$ and ${ }^{232} \mathrm{Th}$

\begin{tabular}{|l|l|}
\hline Radionuclide & $\begin{array}{l}\text { Activity } \\
\text { (Bq/kg) }\end{array}$ \\
\hline${ }^{238} \mathrm{U}$ & 814.7 \\
\hline${ }^{234 T h}$ & 814.7 \\
\hline${ }^{234} \mathrm{~Pa}$ & 813.1 \\
\hline${ }^{234} \mathrm{U}$ & 814.7 \\
\hline${ }^{230 T h}$ & 814.7 \\
\hline${ }^{226} \mathrm{Ra}$ & 814.7 \\
\hline${ }^{222} \mathrm{Rn}$ & 814.7 \\
\hline${ }^{218} \mathrm{Po}$ & 814.7 \\
\hline${ }^{214} \mathrm{~Pb}$ & 814.5 \\
\hline${ }^{214} \mathrm{Bi}$ & 814.7 \\
\hline${ }^{214} \mathrm{Po}$ & 814.5 \\
\hline${ }^{210} \mathrm{~Pb}$ & 814.5 \\
\hline${ }^{210} \mathrm{Bi}$ & 814.5 \\
\hline${ }^{210} \mathrm{Po}$ & 814.5 \\
\hline${ }^{218} \mathrm{At}$ & $1.63 \mathrm{E}-01$ \\
\hline${ }^{234} \mathrm{~Pa}$ & 2.686 \\
\hline${ }^{232} \mathrm{Th}$ & 508.6 \\
\hline${ }^{228} \mathrm{Ra}$ & 508.6 \\
\hline${ }^{228} \mathrm{Ac}$ & 508.6 \\
\hline${ }^{228 T h}$ & 508.6 \\
\hline${ }^{224} \mathrm{Ra}$ & 508.6 \\
\hline${ }^{220} \mathrm{Rn}$ & 508.6 \\
\hline${ }^{212} \mathrm{Po}$ & 508.6 \\
\hline${ }^{212} \mathrm{~Pb}$ & 508.6 \\
\hline${ }^{212} \mathrm{Bi}$ & 508.6 \\
\hline${ }^{212} \mathrm{Po}$ & 325.8 \\
\hline${ }^{208} \mathrm{Ti}$ & 182.7 \\
\hline Dose calculations for external exposure \\
\hline
\end{tabular}

The intruder exposes to an external exposure from all radionuclide that emitted $\gamma$ rays as tabulated in column 1 Table 3 . Using equation (5), the results of the doses from external exposure for each radionuclide are calculated and presented in column 4 Table 3.

In Table 3, despite the short half-life, the bismuth element $\left({ }^{214} \mathrm{Bi}\right)$ shows the highest external dose. On the other hand, the uranium element $\left({ }^{234} \mathrm{U}\right)$ presented the lowest value. It is obvious that the dose conversion factor plays the dominant key in the calculation of dose.

\section{Exposure dose calculations for ingestion}

The intruder receives an ingestion dose, by the ingestion of dust when he is falling on a container, from all radionuclides as presented in column 1 Table 4.

According to equation (6), the quantity of waste intake $\left(Q_{w}\right)$ is considered to be $0.0001 \mathrm{~m}^{3}$ (5.67E-07 $\mathrm{Kg}$ ), the concentration of radionuclides in the waste $\left(C_{w}\right)$ is presented in the column 2 Table 4 . The dose factor of ingestion (DFing) for each radionuclide is presented in column 3 Table 4 . The results of the doses from ingestion for each radionuclide are presented in column 4 Table 4.

The total dose from ingestion for all radionuclides is the summation in the fourth column in Table 4 and is equal 1.60E-09 Sv.

In Table 4 , the lead element $\left({ }^{210} \mathrm{~Pb}\right)$ shows the highest external dose. On the other hand, the protactinium element $\left({ }^{234} \mathrm{~Pa}\right)$ presented the lowest value. Again, the dose conversion plays the first role followed the concentration of the radioelement in case of ${ }^{234} \mathrm{~Pa}$.

From equation (7), the total dose from the inhalation, external exposure and ingestion is calculated and is equal $4.45 \mathrm{E}-08 \mathrm{~Sv}$.

The difference among the three doses of exposure is shown in Figure 1. From the figure it could be noticed that the doses from external exposure are smaller than the doses from the ingestion. The highest dose of exposure is from inhalation of radon gas. The ingestion dose is expected to have the highest dose rather the inhalation of one gas (radon) but depending on the scenario, the intruder swallows a very small amount of dust.

\section{Results of human intrusion scenario in case of storage in under-ground bunkers}

Concerning the scenario of the storage underground, the intruder (security person) exposed to an inhalation dose, external dose and ingestion dose from the dust dispersed in this area from all radionuclides during his surveillance. Exposure dose calculations for inhalation

The grain density of the medium ( $\rho$ ) is $1.34 \mathrm{Kg} / \mathrm{m} 3$. The total porosity of the medium ( $\mathrm{v}$ ) is assumed to be 0.39 for unsaturated zone and the waste soil porosity is 0.27 [13]. $\mathrm{kd}$ is the sorption coefficient of the radionuclide in soil. The retardation factor $\mathrm{R}$ is calculated from equation (11) for each radionuclide as shown in column 3 Table 5.

From equation (10), $C_{\text {soil }}$ is the radionuclide concentration in the soil as presented in column 2 Table 5. X $X_{\text {Dry }}$ is calculated for each radionuclide as shown in column 4, Table 5 . 
Table 3 Input data for the calculation of external dose in case of above-ground storage

\begin{tabular}{|c|c|c|c|}
\hline Radionuclide & $\begin{array}{l}\text { Concentration } \\
\left(\mathrm{A}_{\text {con }}\right) \\
\left(\mathrm{Bq} / \mathrm{m}^{3}\right)\end{array}$ & $\begin{array}{c}\left.\text { DFext }_{\text {ex }}\right] \\
\left(\text { Sv. } \mathrm{m}^{3} / \mathrm{h} . \mathrm{Bq}\right)\end{array}$ & $\begin{array}{l}\text { Dext } \\
\text { (Sv) }\end{array}$ \\
\hline $234 \mathrm{Th}$ & 1091.70 & $1.29 \mathrm{E}-19$ & $3.34 \mathrm{E}-14$ \\
\hline 234Pa m & 1091.70 & 4.20E-19 & $1.08 \mathrm{E}-13$ \\
\hline $234 U$ & 1091.70 & $2.14 \mathrm{E}-21$ & $5.53 \mathrm{E}-16$ \\
\hline $230^{\text {Th }}$ & 1091.70 & $6.39 E-21$ & $1.65 \mathrm{E}-15$ \\
\hline 226Ra & 1091.70 & $1.65 \mathrm{E}-19$ & $4.26 \mathrm{E}-14$ \\
\hline $214 \mathrm{~Pb}$ & 1091.43 & $6.70 \mathrm{E}-18$ & $1.73 \mathrm{E}-12$ \\
\hline $214 \mathrm{Bi}$ & 1091.70 & $4.36 \mathrm{E}-17$ & $1.13 \mathrm{E}-11$ \\
\hline 214Po & 1091.43 & $2.40 \mathrm{E}-21$ & $6.20 \mathrm{E}-16$ \\
\hline $234 \mathrm{~Pa}$ & 3.60 & $5.38 \mathrm{E}-17$ & $4.58 \mathrm{E}-14$ \\
\hline $228^{\text {th }}$ & 681.52 & 4.17E-20 & $6.73 \mathrm{E}-15$ \\
\hline 224Ra & 681.52 & $2.62 \mathrm{E}-19$ & $4.23 \mathrm{E}-14$ \\
\hline $212 \mathrm{~Pb}$ & 681.52 & $3.62 \mathrm{E}-18$ & $5.84 \mathrm{E}-13$ \\
\hline $212 \mathrm{Bi}$ & 681.52 & $5.36 \mathrm{E}-18$ & 8.65E-13 \\
\hline 208Ti & 244.818 & $9.68 \mathrm{E}-17$ & $5.61 \mathrm{E}-12$ \\
\hline Total dose & & & $2.03 \mathrm{E}-11$ \\
\hline
\end{tabular}

Table 4 Input data \& results of ingestion dose in case of above ground storage

\begin{tabular}{|c|c|c|c|}
\hline Radionuclide & $\begin{array}{c}\text { Concentration } \\
\left(\mathbf{C}_{\mathbf{w}}\right) \\
\mathbf{( B q )}\end{array}$ & $\begin{array}{c}\text { DFing[13] } \\
\text { (Sv/Bq) }\end{array}$ & $\begin{array}{c}\text { Ding } \\
\text { (Sv) }\end{array}$ \\
\hline${ }^{238 \mathrm{U}}$ & 16294000 & $6.88 \mathrm{E}-08$ & $3.18 \mathrm{E}-11$ \\
\hline${ }^{234} \mathrm{Th}$ & 16294000 & $3.69 \mathrm{E}-09$ & $1.70 \mathrm{E}-12$ \\
\hline${ }^{234} \mathrm{~Pa}$ & 16262000 & $5.84 \mathrm{E}-10$ & $2.69 \mathrm{E}-13$ \\
\hline${ }^{234} \mathrm{U}$ & 16294000 & $7.66 \mathrm{E}-08$ & $3.54 \mathrm{E}-11$ \\
\hline${ }^{230} \mathrm{Th}$ & 16294000 & $1.48 \mathrm{E}-07$ & $6.84 \mathrm{E}-11$ \\
\hline${ }^{226} \mathrm{Ra}$ & 16294000 & $3.58 \mathrm{E}-07$ & $1.65 \mathrm{E}-10$ \\
\hline${ }^{214} \mathrm{~Pb}$ & 16290000 & $1.69 \mathrm{E}-10$ & $7.80 \mathrm{E}-14$ \\
\hline${ }^{214} \mathrm{Bi}$ & 16294000 & $7.64 \mathrm{E}-11$ & $3.53 \mathrm{E}-14$ \\
\hline${ }^{210} \mathrm{~Pb}$ & 16290000 & $1.45 \mathrm{E}-06$ & $6.70 \mathrm{E}-10$ \\
\hline${ }^{210} \mathrm{Bi}$ & 16290000 & $1.73 \mathrm{E}-09$ & $7.99 \mathrm{E}-13$ \\
\hline${ }^{210} \mathrm{Po}$ & 16290000 & $5.14 \mathrm{E}-07$ & $2.37 \mathrm{E}-10$ \\
\hline${ }^{234} \mathrm{~Pa}$ & 53720 & $5.84 \mathrm{E}-10$ & $8.89 \mathrm{E}-16$ \\
\hline${ }^{232} \mathrm{Th}$ & 10172000 & $7.38 \mathrm{E}-07$ & $2.13 \mathrm{E}-10$ \\
\hline${ }^{228} \mathrm{Ra}$ & 10172000 & $3.88 \mathrm{E}-07$ & $1.12 \mathrm{E}-10$ \\
\hline${ }^{228} \mathrm{Ac}$ & 10172000 & $5.85 \mathrm{E}-10$ & $1.69 \mathrm{E}-13$ \\
\hline${ }^{228} \mathrm{Th}$ & 10172000 & $1.07 \mathrm{E}-07$ & $3.09 \mathrm{E}-11$ \\
\hline${ }^{224} \mathrm{Ra}$ & 10172000 & $9.89 \mathrm{E}-08$ & $2.85 \mathrm{E}-11$ \\
\hline${ }^{212} \mathrm{~Pb}$ & 10172000 & $1.23 \mathrm{E}-08$ & $3.55 \mathrm{E}-12$ \\
\hline${ }^{212} \mathrm{Bi}$ & 10172000 & $2.87 \mathrm{E}-10$ & $8.28 \mathrm{E}-14$ \\
\hline $40 \mathrm{~K}$ & 4696400 & $5.02 \mathrm{E}-09$ & $6.68 \mathrm{E}-13$ \\
\hline$T 0 t a \mathrm{~d} \mathrm{dose}$ & & & $1.60 \mathrm{E}-09$ \\
\hline & & & \\
\hline
\end{tabular}

The dust level in the air above the surface soil (CDust) is assumed to be equal $0.000001 \mathrm{Kg} / \mathrm{m}^{3}$ [14] Equation (9) is used to calculate $\mathrm{C}_{\text {Air. }}$. The calculated values are tabulated in column 2 Table 6.

From equation (8), the individual occupancy on the contaminated soil (Oout) is assumed to be $8647.058824 \mathrm{~h} / \mathrm{y}[8]$, the breathing rate of human on the contaminated soil (Inhsed) is considered to be
$1.2 \mathrm{~m}^{3} / \mathrm{h}$ and the dose coefficient for inhalation ( $D C_{1 \mathrm{nh}}$ ) for each radionuclide is presented in column 3 in Table 6. Consequently, the inhalation dose for each radionuclide (EDust) is calculated and presented in column 4 Table 6. 


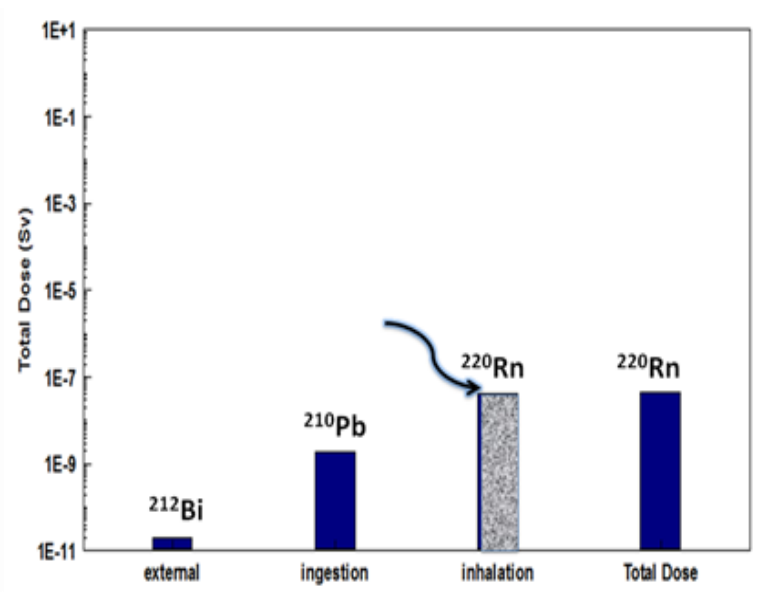

Figure 1 Dose received by the intruder in case of the above-ground storage
From Table 6, the inhalation dose calculated for radon gas is null value. This value is expected because the gas is diluted and dispersed in the air continuously. ${ }^{234} \mathrm{~Pa}$ is contributed by a lower value in the total dose. On the other hand, the dominant radionuclide in the inhalation dose is the ${ }^{232} \mathrm{Th}$. Dose calculations for external exposure

From equation (12), the intruder occupancy outdoors on the contaminated soil (O Out) is considered to be $8647.058824 \mathrm{~h} / \mathrm{y}$ [8]. The dose coefficient factor for external irradiation from soil ( $D C_{\text {Exts }}$ ) is presented in the column 3 Table 7 . The intruder dose from external irradiation from soil (EDust) is calculated and presented in column 4 Table 7.

In Table 7, despite the short half-life, the bismuth element $\left({ }^{214} \mathrm{Bi}\right)$ shows the highest external dose. On the other hand, the ${ }^{234} \mathrm{U}$ is considered the lowest dose value.

Table 5 Input data for calculation of inhalation dose in case of under-ground storage

\begin{tabular}{|c|c|c|c|}
\hline $\begin{array}{l}\text { Radion- } \\
\text { uclide }\end{array}$ & $\begin{array}{l}\text { Concentration } \\
\left(\mathrm{C}_{\text {soil }}\right) \\
(\mathrm{Bq} / \mathrm{Kg})\end{array}$ & $\begin{array}{l}K_{d}[8] \\
\left(m^{3} / K g\right)\end{array}$ & $\begin{array}{l}\text { X Dry } \\
\text { (Bq/Kg) }\end{array}$ \\
\hline${ }^{238} \mathrm{U}$ & 244.41 & 3.30E-02 & 199339.4 \\
\hline 234Th & 244.41 & $3.00 E+00$ & 199339.4 \\
\hline${ }^{234} \mathrm{~Pa}$ & 243.93 & $5.40 \mathrm{E}-01$ & 198947.9 \\
\hline${ }^{234} \mathrm{U}$ & 244.41 & 3.30E-02 & 199339.4 \\
\hline 230Th & 244.41 & $3.00 E+00$ & 199339.4 \\
\hline${ }^{226} \mathrm{Ra}$ & 244.41 & $4.90 \mathrm{E}-01$ & 199339.4 \\
\hline${ }^{222} \mathrm{Rn}$ & 244.41 & $0.00 \mathrm{E}+00$ & 199339.4 \\
\hline${ }^{214} \mathrm{~Pb}$ & 244.35 & $2.70 \mathrm{E}-01$ & 199290.4 \\
\hline${ }^{214} \mathrm{Bi}$ & 244.41 & $1.00 \mathrm{E}-01$ & 199339.4 \\
\hline${ }^{210} \mathrm{~Pb}$ & 244.35 & $2.70 \mathrm{E}-01$ & 199290.4 \\
\hline${ }^{210} \mathrm{Bi}$ & 244.35 & $1.00 \mathrm{E}-01$ & 199290.4 \\
\hline${ }^{210} \mathrm{Po}$ & 244.35 & $1.50 \mathrm{E}-01$ & 199290.4 \\
\hline${ }^{234} \mathrm{~Pa}$ & 0.8058 & $5.40 \mathrm{E}-01$ & 657.2058 \\
\hline${ }^{232} \mathrm{Th}$ & 152.58 & $3.00 \mathrm{E}+00$ & 124443.4 \\
\hline${ }^{228} \mathrm{Ra}$ & 152.58 & 4.90E-01 & 124443.4 \\
\hline${ }^{228} \mathrm{Ac}$ & 152.58 & 4.50E-01 & 124443.4 \\
\hline 228Th & 152.58 & $3.00 \mathrm{E}+00$ & 124443.4 \\
\hline${ }^{224} \mathrm{Ra}$ & 152.58 & $4.90 \mathrm{E}-01$ & 124443.4 \\
\hline${ }^{212} \mathrm{~Pb}$ & 152.58 & $2.70 \mathrm{E}-01$ & 124443.4 \\
\hline${ }^{212} \mathrm{Bi}$ & 152.58 & $1.00 \mathrm{E}-01$ & 124443.4 \\
\hline${ }^{40} \mathrm{~K}$ & 70.446 & 0.7575 & 57455.35 \\
\hline
\end{tabular}

\section{Exposure dose calculations for ingestion dose}

From equation (14), the density of the water is $1000 \mathrm{Kg} / \mathrm{m} 3$ and the concentration of radionuclides (CSoil) is presented in column 2 Table 8 . Consequently $\mathrm{XWet}$ is calculated for each radionuclide as shown in column 3, Table 8 .

From equation (13), the ingestion rate of soil by the intruder (Ingsed) is $0.0004998 \mathrm{Kg} / \mathrm{y}$ [8] and the dose coefficient for ingestion (DCing) is presented in column 4 Table 6-8. Consequently, the ingestion dose receive(Esed) is calculated and presented in column 5 , Table 8.

In Table 8 , the lead element (210Pb) shows the highest external dose and the protactinium element $(234 \mathrm{~Pa})$ presented the lowest value.
The total dose from the ingestion for all radionuclides is the summation of each result in the fifth column in Table 8 and equal 1.75E-09 Sv.

The difference among the three doses of exposure is shown in Figure 2. From the figure, the doses from external exposure are smaller than the doses from the ingestion. The highest dose of exposure is from the inhalation of radionuclides.

Also a comparison between different doses will be received through the human intrusion scenarios above-ground and under-ground is given in Table 9.

From equation (15), the total dose from inhalation, external exposure and ingestion for underground is calculated and equal 1.29E-03 Sv.

Figure 3 shows the high gap between total doses in the human intrusion scenarios above-ground and underground. 
Table 6 results of inhalation dose in case of under-ground storage

\begin{tabular}{|c|c|c|c|}
\hline $\begin{array}{l}\text { Radion- } \\
\text { Uclide }\end{array}$ & $\begin{array}{c}\text { Cair } \\
\left(\mathrm{Bq} / \mathrm{m}^{3}\right)\end{array}$ & $\begin{array}{c}C_{\text {inh }}[13] \\
\text { (Sv/Bq) }\end{array}$ & $\begin{array}{l}\text { EDust } \\
\text { (Sv) }\end{array}$ \\
\hline${ }^{238} \mathrm{U}$ & $1.81 \mathrm{E}-02$ & $6.62 \mathrm{E}-07$ & $2.09 \mathrm{E}-07$ \\
\hline 234Th & $1.81 \mathrm{E}-02$ & 8.04E-09 & $2.51 \mathrm{E}-08$ \\
\hline${ }^{234} \mathrm{~Pa}$ & $1.23 \mathrm{E}-01$ & $1.98 \mathrm{E}-10$ & 4.26E-10 \\
\hline${ }^{234} \mathrm{U}$ & 1.81E-02 & 7.37E-07 & $2.32 \mathrm{E}-07$ \\
\hline 230Th & $1.80 \mathrm{E}-01$ & $8.80 \mathrm{E}-05$ & $2.75 \mathrm{E}-04$ \\
\hline${ }^{226} \mathrm{Ra}$ & $1.19 \mathrm{E}-01$ & $2.32 \mathrm{E}-06$ & 4.81E-06 \\
\hline${ }^{222} \mathrm{Rn}$ & $0.00 \mathrm{E}+00$ & $2.40 \mathrm{E}-09$ & $0.00 E+00$ \\
\hline${ }^{214} \mathrm{~Pb}$ & 8.96E-02 & 2.11E-09 & $3.29 \mathrm{E}-09$ \\
\hline${ }^{214} \mathrm{Bi}$ & 4.63E-02 & 1.78E-09 & $3.37 \mathrm{E}-09$ \\
\hline${ }^{210} \mathrm{~Pb}$ & 8.96E-02 & 3.67E-06 & $5.73 \mathrm{E}-06$ \\
\hline${ }^{210} \mathrm{Bi}$ & 4.63E-02 & 4.18E-09 & 3.37E-09 \\
\hline${ }^{210} \mathrm{Po}$ & $6.22 \mathrm{E}-02$ & $2.54 \mathrm{E}-06$ & $2.75 \mathrm{E}-06$ \\
\hline${ }^{234} \mathrm{~Pa}$ & $4.08 \mathrm{E}-04$ & $1.98 \mathrm{E}-10$ & $1.41 \mathrm{E}-12$ \\
\hline${ }^{232} \mathrm{Th}$ & $1.12 \mathrm{E}-01$ & $4.43 E-04$ & $8.65 \mathrm{E}-04$ \\
\hline${ }^{228} \mathrm{Ra}$ & 7.43E-02 & $1.29 \mathrm{E}-04$ & $1.67 \mathrm{E}-06$ \\
\hline${ }^{228} \mathrm{Ac}$ & $7.18 \mathrm{E}-02$ & 8.33E-08 & $1.04 \mathrm{E}-07$ \\
\hline $228 \mathrm{Th}$ & $1.12 \mathrm{E}-01$ & $6.75 \mathrm{E}-05$ & $1.32 \mathrm{E}-04$ \\
\hline${ }^{224} \mathrm{Ra}$ & $7.43 \mathrm{E}-02$ & $8.53 \mathrm{E}-07$ & $1.10 \mathrm{E}-06$ \\
\hline${ }^{212} \mathrm{~Pb}$ & $5.60 \mathrm{E}-02$ & $4.56 \mathrm{E}-08$ & $4.44 \mathrm{E}-08$ \\
\hline${ }^{212} \mathrm{Bi}$ & $2.89 \mathrm{E}-02$ & 5.83E-09 & $2.94 \mathrm{E}-09$ \\
\hline${ }^{40} \mathrm{~K}$ & $4.00 \mathrm{E}-02$ & $3.34 \mathrm{E}-09$ & $2.33 \mathrm{E}-09$ \\
\hline Total & & & $1.29 \mathrm{E}-03$ \\
\hline
\end{tabular}

Table 7 Input data \& external dose results Of radionuclides in case of under-ground storage

\begin{tabular}{|c|c|c|c|}
\hline $\begin{array}{l}\text { Radion- } \\
\text { Uclides }\end{array}$ & $\begin{array}{c}\text { Concentration } \\
\left(\mathrm{Bq} / \mathrm{m}^{3}\right)\end{array}$ & $\begin{array}{c}D_{\text {ext }}[12] \\
\left(S v \mathrm{~m}^{3} / \mathrm{h} \mathrm{Bq}\right)\end{array}$ & $\begin{array}{l}\text { Eext } \\
\text { (Sv) }\end{array}$ \\
\hline $234 \mathrm{Th}$ & 327.5094 & $1.29 \mathrm{E}-19$ & $2.20698 \mathrm{E}-12$ \\
\hline${ }^{234} \mathrm{~Pa} \mathrm{~m}$ & 326.8662 & 4.20E-19 & $7.17139 \mathrm{E}-12$ \\
\hline${ }^{234} U$ & 327.5094 & $2.14 \mathrm{E}-21$ & $3.66119 \mathrm{E}-14$ \\
\hline 230Th & 327.5094 & $6.39 E-21$ & $1.09322 \mathrm{E}-13$ \\
\hline${ }^{226} \mathrm{Ra}$ & 327.5094 & $1.65 E-19$ & $2.82288 \mathrm{E}-12$ \\
\hline${ }^{214} \mathrm{~Pb}$ & 327.429 & $6.70 \mathrm{E}-18$ & $1.14598 \mathrm{E}-10$ \\
\hline${ }^{214} \mathrm{Bi}$ & 327.5094 & $4.36 \mathrm{E}-17$ & 7.45924E-10 \\
\hline${ }^{214} \mathrm{Po}$ & 327.429 & $2.4 \mathrm{E}-21$ & 4.10499E-14 \\
\hline${ }^{234} \mathrm{~Pa}$ & 1.079772 & $5.38 \mathrm{E}-17$ & $3.03458 \mathrm{E}-12$ \\
\hline 228Th & 204.4572 & 4.17E-20 & $4.45372 \mathrm{E}-13$ \\
\hline${ }^{224} \mathrm{Ra}$ & 204.4572 & $2.62 \mathrm{E}-19$ & $2.79826 \mathrm{E}-12$ \\
\hline${ }^{212} \mathrm{~Pb}$ & 204.4572 & $3.62 \mathrm{E}-18$ & 3.8663E-11 \\
\hline${ }^{212} \mathrm{Bi}$ & 204.4572 & $5.36 \mathrm{E}-18$ & $5.72468 \mathrm{E}-11$ \\
\hline${ }^{208} \mathrm{Ti}$ & 73.4454 & $9.68 \mathrm{E}-17$ & $3.71385 \mathrm{E}-10$ \\
\hline Total & & & 1.34648E-09 \\
\hline
\end{tabular}




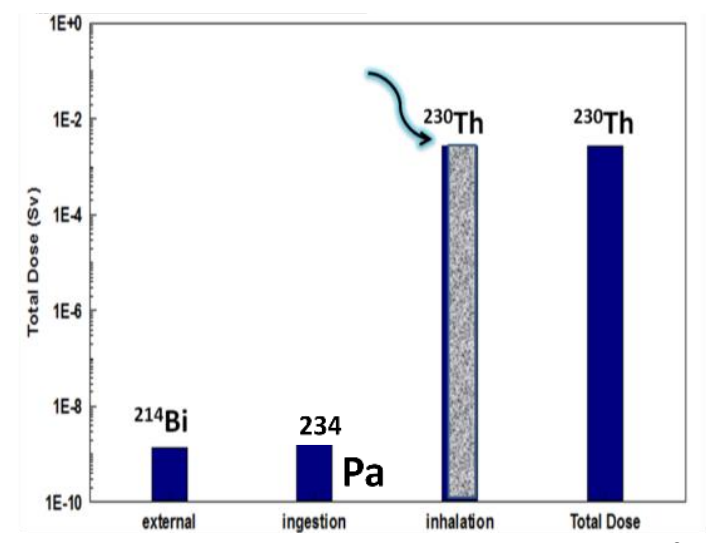

Figure 2 Dose Received by the Intruder in Case of the Under-Ground Storage.

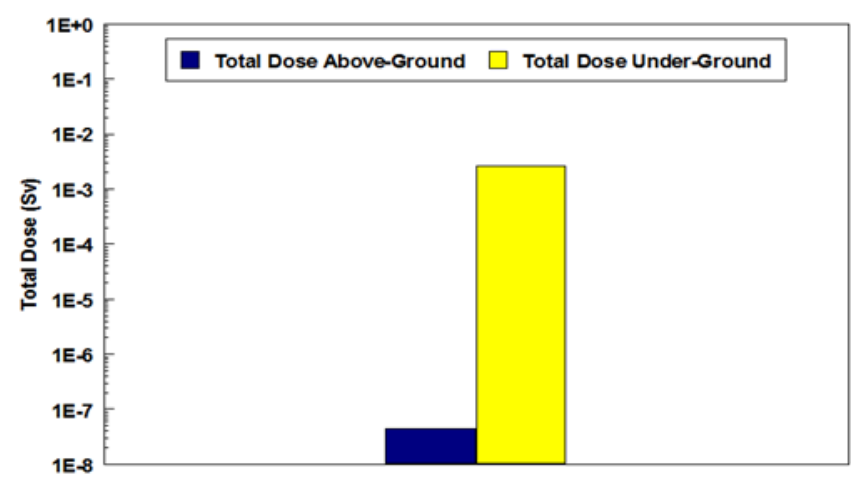

Figure 3 Comparison of Total Dose Received by the Intruder

Table 8 Input data \& ingestion dose results of radionuclides in case of under-ground storage

\begin{tabular}{|c|c|c|c|c|}
\hline Radionuclide & $\begin{array}{c}\text { Concentration } \\
\left(\mathrm{Bq} / \mathrm{m}^{3}\right)\end{array}$ & $\begin{array}{c}X_{w e t} \\
(\mathrm{~Bq} / \mathrm{Kg})\end{array}$ & $\begin{array}{l}\text { DF ing[13] } \\
\text { (Sv/Bq) }\end{array}$ & $\begin{array}{l}\text { E sed } \\
\text { (Sv) }\end{array}$ \\
\hline${ }^{238} \mathrm{U}$ & 327.5094 & 601.66 & $6.88 \mathrm{E}-08$ & $3.47 \mathrm{E}-11$ \\
\hline 234Th & 327.5094 & 601.66 & 3.69E-09 & $1.86 \mathrm{E}-12$ \\
\hline${ }^{234} \mathrm{~Pa}$ & 326.8662 & 600.4784 & $5.84 \mathrm{E}-10$ & $2.94 \mathrm{E}-13$ \\
\hline${ }^{234} U$ & 327.5094 & 601.66 & $7.66 \mathrm{E}-08$ & $3.87 \mathrm{E}-11$ \\
\hline 230Th & 327.5094 & 601.66 & $1.48 \mathrm{E}-07$ & $7.47 \mathrm{E}-11$ \\
\hline${ }^{226} \mathrm{Ra}$ & 327.5094 & 601.66 & $3.58 \mathrm{E}-07$ & $1.81 \mathrm{E}-10$ \\
\hline${ }^{214} \mathrm{~Pb}$ & 327.429 & 601.5123 & $1.69 \mathrm{E}-10$ & $8.53 \mathrm{E}-14$ \\
\hline${ }^{214} \mathrm{Bi}$ & 327.5094 & 601.66 & 7.64E-11 & $3.86 \mathrm{E}-14$ \\
\hline${ }^{210} \mathrm{~Pb}$ & 327.429 & 601.5123 & $1.45 \mathrm{E}-06$ & 7.32E-10 \\
\hline${ }^{210} \mathrm{Bi}$ & 327.429 & 601.5123 & $1.73 \mathrm{E}-09$ & 8.73E-13 \\
\hline${ }^{210} \mathrm{Po}$ & 327.429 & 601.5123 & $5.14 \mathrm{E}-07$ & $2.59 \mathrm{E}-10$ \\
\hline${ }^{234} \mathrm{~Pa}$ & 1.079772 & 1.983624 & $5.84 \mathrm{E}-10$ & $9.72 \mathrm{E}-16$ \\
\hline${ }^{232} \mathrm{Th}$ & 204.4572 & 375.6036 & $7.38 \mathrm{E}-07$ & $2.32 \mathrm{E}-10$ \\
\hline${ }^{228} \mathrm{Ra}$ & 204.4572 & 375.6036 & $3.88 \mathrm{E}-07$ & $1.22 \mathrm{E}-10$ \\
\hline${ }^{228} \mathrm{AC}$ & 204.4572 & 375.6036 & $5.85 \mathrm{E}-10$ & $1.84 \mathrm{E}-13$ \\
\hline 228Th & 204.4572 & 375.6036 & 1.07E-07 & 3.37E-11 \\
\hline${ }^{224} \mathrm{Ra}$ & 204.4572 & 375.6036 & $9.89 \mathrm{E}-08$ & 3.12E-11 \\
\hline${ }^{212} \mathrm{~Pb}$ & 204.4572 & 375.6036 & $1.23 \mathrm{E}-08$ & $3.87 \mathrm{E}-12$ \\
\hline $212 \mathrm{Bi}$ & 204.4572 & 375.6036 & 2.87E-10 & $9.04 \mathrm{E}-14$ \\
\hline $40 \mathrm{~K}$ & 94.39764 & 173.4157 & $5.02 \mathrm{E}-09$ & 7.30E-13 \\
\hline Total & & & & $1.75 \mathrm{E}-09$ \\
\hline
\end{tabular}

Table 9 Comparison between the two scenarios.

\begin{tabular}{|lrc|} 
& Above(SV) & \multicolumn{1}{c|}{ Under(Sv) } \\
\hline Inhalation & $4.29 \mathrm{E}-08$ & $1.29 \mathrm{E}-03$ \\
\hline Ingestion & $1.60 \mathrm{E}-09$ & $1.75 \mathrm{E}-09$ \\
External & $2.02 \mathrm{E}-11$ & $1.35 \mathrm{E}-09$ \\
\hline
\end{tabular}

\section{Conclusion}

The long term interim storage of long-live NORM waste is an only option considered in case of nonavailable disposal. The safety evaluation for the storage was performed. From the present study, it could be concluded that: 
1. By using human intrusion scenario, the total dose received by an intruder in the aboveground storage is lower than the total dose in the under-ground storage.

2. For future, above-ground storage is recommended as a safer design for long term storage.

3. Careful and regular maintenance of safety and security measures shall be maintained until the final disposal of NORM.

4. Loss of records or maintenance shall not be allowed or permissible in case of long-term storage

5. Long term storage shall be limited to a fixed time as an agreement (between generator and regulatory body) for final disposal of NORM.

\section{References}

[1] Http://www.wordiq.com/definition/waste

[2] IAEA-TECDOC-Management of low and intermediate level radioactive wastes with regard to their chemical toxicity,1325, December, 2002

[3] IAEA- Extent of Environmental Contamination by Naturally Occurring Radioactive Material (NORM) Anf Technological Options For Mitigation-Technical Reports Series No. 419-VIENNA, 2003

[4] Nuclear Energy Agency (NEA), Future Human Action At disposal Sites, OECD,1995

[5] Douglas J. Wagenaar, Radioactivity in Equilibrium. October.

[6] http://www.med.harvard.edu/jpnm/physics/nmltd/ra dprin/main.html,1995 .

[7] IAEA, Derivation of Activity Limits for the Disposal of Radioactive Waste in Near Surface Disposal Facilities. TECDOC-1380. December, 2003.

[8] Savidou A., Tzika F., Stamatelatos I. E. 4th International Conference on NDT, Hellenic Society for NDT, Chania, Crete-Greece Institute of Nuclear Technology and Radiation Protection, NCSR 'Demokritos', 11-14 October, 2007.

[9] IAEA, Vault Safety Case, Working document: ISAM/SCWG/WD01, Vienna, August, 2001

[10] IAEA, Radon Type Facility Safety Case Report, Working Document: ISAM/SCWG/WD02, Vienna, October, 2001

[11] John Bradbury, Scientific Notebook - Secular Equilibrium Assumption Analysis, Volume 3, 2010

[12] http://www.wise-uranium.org/rcc.html

[13] EPA, External Exposure to Radionuclides in Air, Water, and Soil, Federal Guidance Report No.12, September, 1993

[14] EPA, Limiting Values of Radionuclides Intake and Air Concentration And Dose Conversion Factors For Inhalation, Submersion, and Ingestion, Federal Guidance Report No.11, September, 1988.

[15] Cheng H, Edwards RL, Hoff J, Gallup CD, Richards DA, Asmerom $Y$, The half-lives of uranium-234 and thorium-230. Chem Geol 169:17-33, 2000. 